\title{
The First cut is the deepest: reflections on the state of animal dissection in biology education
}

\section{Rian de Villiers and Martin Monk}

In biology education, the study of structure has traditionally involved the use of dissection. Animal-rights campaigners have caused biology educators and learners to question the necessity of dissections. This study reviews the research evidence for the efficacy of alternatives to dissection and then turns to research evidence on attitudes to dissection. It suggests that the place, practice, and purpose of dissection in biology education can act as an indicator of the state of society in which those practices are embedded. The current situation in

South Africa is reviewed to illustrate how social factors outside the laboratory influence pedagogic practice.

Keywords: anatomy; biology; dissection; laboratory animals; laboratory procedures; science instruction.

To cut or not to cut: that is the curricular question. However, the first cut is the deepest, because the first cut is the cut that kills. Should educators, in the 21st century, still be killing animals to help young people learn about the internal structure of animals? There are pedagogical as well as ethical aspects to this question.

The answers any society finds to such questions, at any period in time, are located within wider political and socio-economic frameworks. What is taken as acceptable practice for teaching structure and function in biology is not hermetically sealed within biological education. Different practices are possible, and these practices evolve as wider debates about difference and similarity, rights and responsibilities seep into the academy, classroom, and laboratory. What is acceptable practice in the laboratory is an indicator of the state of such debates in the wider society.

We are not the first to raise questions about the nature and place of dissection in biology education. In some countries, particularly Northern and Western ones, these questions have long been debated, while in others, such as those in Africa, the debate is just entering the public domain. In Northern and Western countries, the last quarter of the 20th century saw science education being re-negotiated as science for all. In the early years of the 21st century the nature of that science for all is itself being questioned. Should it be science education for scientists, a continuation of what has happened in the past, or should it be science for citizenship, something quite different? If it is to be science for citizenship, then what stays and what goes? What are the new organizing principles, and what are the general curricular implications? The question of the use or abolition of animal dissections is 
not just some small item within the biology curriculum; it is an indicator of the state of the society.

Later in this paper, we turn to South Africa as an example of changes in the use of dissections and how they can be used as an indicator for wider changes occurring in the school curriculum and society beyond the school gate. The situation in the Republic of South Africa provides an interesting case, because it is a country in transition. Politically, the old segregated past is giving way to a new inclusive future. A re-writing of the curriculum has meant that many of the old assumptions about in what should be taught, to whom, at what stage, and how, have been under sharper scrutiny than in other countries where change has been a less radical.

\section{Background}

There is an inherent contradiction in killing animals and cutting them up to study the processes of life. However, how else does one find out about how organisms are structured and how tissues and organs are connected? What are the curricular implications of alternatives?

\section{History}

Dissection has been the traditional way to expose and learn about animal structure. Dissection has an ancient and classical lineage, the documentation of which can be traced back to Aristotle's work on such things as embryology, and Galen's publication of the results of his investigations on animals. ${ }^{1}$ Galen never carried out vivisection on gladiators, but he benefited from the detailed knowledge gained by those who attended gladiators' injuries. Vesalius (born Andreas van Wesel, 1514-1564) in the 16th century was perhaps the greatest anatomist. He took advantage of the papal ruling of 1540 that cadavers of those who had committed sins that would condemn them to hell could be used for dissection. Even then, the theological problems associated with the resurrection of the body continued to limit the supply of human corpses in Europe. In the early-19th century, Burke and Hare of Edinburgh became among the most celebrated suppliers of bodies for a medical school as they turned to murder to maintain their trade.

\section{Researching}

The historical legacy of dissection is accumulated knowledge. Dissection has provided knowledge of structure in animals that could not have gained in any other way. ${ }^{2}$ Where dead animals provide knowledge of structure, living ones provide knowledge of function.

In the second half of the 20th century, advances in commercial medicine, under ever-tighter government regulation, meant an explosive growth in the 
number of tests carried out on animals to ensure that treatments were effective and safe for humans. Such a situation is quite striking when set alongside medical understanding moving more and more towards cellular process and biochemical mechanisms. In commercial and academic research laboratories there are conflicting pressures: one pressure is to be sure of the safety of treatments through tests carried out on whole organisms; the other pressure is to reduce the number of whole organisms used, to avoid needless suffering and cruelty. Both these pressures come from public opinion in society at large.

Doubtless, animal-rights movements have had a large part to play in raising the issue, questioning established practice, and, in some cases, taking violent action to protect animals' rights. In commercial research, the most widely used alternatives to living animals are cell cultures, isolated organs, and computer models. However, will alternatives replace animal experiments completely?

\section{Teaching}

The number of animals used for teaching are few compared to the larger numbers used in research. The use of dissection in biology education, as part of mass education rather than medical training, began in the early 20th century (Kinzie et al. 1993). In schools, colleges, and universities there continues to be debate about the role of dissection, especially of mammals, in biology education. While some educators and scientists (Rowan 1981, Orlans 1988a, b, 1991, Gilmore 1991, Davis 1997) have advocated the replacing of animal dissection with alternatives, others (Lord 1990, Smith 1990, Keiser and Hamm 1991, Lock 1993, Offner 1993, Wheeler 1993, Kline 1995) have, at one stage or another, expressed support for dissection. Over the last three decades, the increasing public visibility of animal-rights campaigners in Northern and Western society at large has influenced opinion in the academy among both teachers and learners. There has been a reduction in the number of animal dissections, and even complete abolition in some countries. In schools, colleges, and universities, alternatives to dissection have been sought, tested, and in some cases evaluated.

In the 1980s, animal dissection in biology education was formally challenged. Learners began not only to object to dissection, but to refuse to participate and demand alternative assignments. Legislation has now been passed in California and Florida protecting the rights of students who do not wish to participate in animal dissections (Orlans 1988a). Wheeler (1993) contended that, since 1990, no UK General Certificate of Secondary Education A-level biology curriculum has required that any whole animal be dissected.

\section{Alternatives}

In Northern and Western countries, the trend has been to reduce the 
number of live animals used for teaching purposes and to replace dissection with acceptable alternatives. Finding such alternatives is becoming an increasingly important task worldwide. The alternatives available today include 'low-tech' variants such as preserved specimens, books, charts, slides, photographs, and three-dimensional anatomical models, and 'hightech' variants such as computer-based simulations, films, and interactive videodisc-based simulations. Greenfield et al. (1995) contend that an alternative method of teaching should be considered acceptable if it allows learners to reach at least the same level of proficiency as they would have if the information had been taught in the traditional manner. However, are there alternatives that have proven to be as effective in accomplishing the requisite learning outcomes? How has technology had a bearing on the learning of biological systems and structure? One purpose of the review of research that follows is to examine the evidence for the educational effectiveness of the alternatives to animal dissection. We will compare the advantages and disadvantages of the alternatives.

\section{How effective are alternatives?}

There are relatively few studies evaluating the instructional effectiveness of alternative experiences to animal dissections; there are more reports of practice than evaluations of that practice. Where studies have been carried out, the majority of alternatives involve film, video, video-disc, or audiocassettes; only a few involve the use of models. Not surprisingly, research on the effectiveness of computer simulations has been carried out more recently. Our review is presented in a chronological sequence because the renegotiation of practice in society follows a trajectory through time.

\section{The 1960s}

As early as 1968, Fowler and Brosius studied the effectiveness of film-based instructional activities as alternatives to animal dissection. Their study involved 10th-grade biology learners working on vertebrate anatomy. The results indicated that learning from film was more effective than learning from a dissection in the declarative knowledge about each specimen. For assessment of the manipulation of laboratory dissecting implements, Fowler and Brosius report that learning from film was found to be as effective as the dissection itself. However, the finding was based on what seems to be a naïve design. They tested for this skill by presenting learners with white plastic polythene sheets with figures printed on the sheet. Each learner was asked to cut around the figures. Each of the figures was cross-hatched with ticks at $1 / 8$ th of an inch $(2.5 \mathrm{~cm})$ intervals. Scoring was according to how much the students deviated from the figure into the surrounding area. This was used both pre- and post-treatment.

Welser (1969) used silent-film loops as an alternative to dissection. In 
the study, veterinary learners were placed into three groups: first, those who used the film loops as a substitute for a prosected cadaver (the pre-dissected example), together with the learners practising dissecting on a cadaver; secondly, the study of a prosected cadaver and dissection of a cadaver; thirdly, only the use of film loops as the primary instructional method. The post-tests were pencil-and-paper tasks that assessed declarative rather than procedural knowledge. Post-tests taken immediately following the instruction indicated that use of the film loops alone were just as effective as study of a prosected cadaver with dissection (the traditional way of teaching). Quite surprisingly, post-tests delayed by a month indicated that learners who used the film loops scored, in general, significantly higher on declarative knowledge than those who studied a prosected and dissected cadaver. A film alternative appeared to be better.

\section{The 1970s}

As a substitute for dissection Prentice et al. (1977) used stereoscopic slides with printed text and audiocassettes for an anatomy auto-instruction programme. Physical-therapy, physician-assistant, and graduate learners were involved in the study. The stereoscopic anatomy auto-instructional programme appeared to be a very effective method of teaching the learners to identify anatomical structures. Learning outcomes as measured on written examinations showed no significant differences. The main complaint of the learners using this programme was the difficulty they experienced in trying to establish an overall anatomical orientation. Of course, the programme does not provide the learner with an opportunity to develop a tactile awareness of the structure of the body, which is important to the understanding of three-dimensional anatomy. In the face of severe shortages of anatomical donors, this programme was thought a good compromise.

Jones et al. (1978) also evaluated the effectiveness of alternatives to dissection. They found that learning on declarative knowledge by medical learners using computer-assisted instruction, audio-visuals, and prosected human cadavers, taken together, was equivalent to that of students taught using the traditional lectures and hands-on dissection programme.

\section{The 1980s}

In the late 1980s, Clarke (1987) investigated the use of microcomputer simulations in undergraduate neuro-physiology experiments. The study of examination results gained by two groups of learners taking the same course before and after the availability of computer simulations showed no differences in attainment. Realistic simulations, according to Clarke, can fulfil most of the teaching objectives of the conventional experiment.

A year later, McCollum (1988) reported attempts to determine the effect 
of animal dissection on learners' acquisition of knowledge. This study involved learners of biology classes in a secondary school. One group performed a highly-structured frog dissection to learn about frog structure, function, and adaptation. The second group learned about these features from a lecture. He found that the learners taught in the lecture scored significantly higher on the written unit test than those conducting actual dissections.

Leonard (1989) reported that his sample of university learners in an introductory biology class, who had accessed laboratory simulations using an interactive video-disc, gave significantly more positive responses than did learners who performed the actual laboratory investigations to post-laboratory questionnaire items on their level of declarative knowledge, understanding of experimental results, time-efficiency, and general satisfaction with what was learned. No significant differences were found between the laboratory investigation and the interactive videodisc-based simulation instructional methods in the learners' understanding of principles, levels of interest in the lesson content, and levels of confusion and boredom. Where there was dissatisfaction with the simulation, the major cause was that the learners missed handling actual experimental apparatus and specimens, and that they missed having written instructions.

Note that these studies were carried out in a climate that had gradually come to endorse the use of alternatives to dissection. Doubtless, attitudes amongst the public-at-large have been gradually shaped by animal-rights campaigners. While few would actually endorse the violent action of a handful of campaigners, many would now support the idea that animals should be treated with respect.

\section{The 1990s}

Strauss and Kinzie (1991) designed an interactive videodisc-based frog dissection programme and Kinzie et al. (1993) reported their study of the effectiveness of the simulation. They examined the performance and achievement of their sample of secondary-school biology learners using the simulation in two ways: first, as a substitute for dissection; and, secondly, as a preparatory tool used prior to dissection. The findings show that the interactive videodisc-based simulation was at least as effective as actual dissection in promoting student declarative knowledge of frog anatomy and dissection procedures. The interactive videodisc appears to offer more effective interaction with the topic than the actual specimen, probably because it is guided and open to repetition and can be used at the learner's own pace. Using the interactive videodisc as a preparation for actual dissection, learners performed a subsequent dissection more effectively than learners viewing a videotape as preparation. Not surprisingly, the results also showed that learners using the interactive programme as a preparation also knew more about frog 
anatomy and dissection procedures than those who dissected without preparation.

Dewhurst et al. (1994) studied the effectiveness of a computer-simulation as an alternative for teaching the principles of intestinal absorption. A sample of honours physiology learners was divided into a simulation and a conventional group, and their achievement gain was tested with a researcher-produced post-test. The evaluation demonstrated that the learners who used the computer simulation achieved the same level of knowledge as those working in the laboratory. Primary learning objectives were equally achieved by both approaches.

Downie and Meadows (1995) reported a scheme wherein universitylevel first-year biology learners were given a choice between dissecting a rat or opting out and doing an equivalent laboratory exercise using models, charts, and demonstrators as alternatives. Over the 10 examinations recorded, opt-out and non-opt-out learners recorded exactly the same mean mark. Opt-out students generally found the model rat satisfactory as an alternative to the real thing (a somewhat puzzling finding as they presumably had not worked with the real thing).

In 1995, Greenfield et al. reported a study comparing the surgical skills of third-year veterinary learners trained using soft-tissue organ models or live animals. They detected no significant difference in surgical skills between the models-trained group and the traditionally-trained group.

\section{In summary}

What little research evidence there is points to the following conclusions:

- Declarative knowledge is equal, if not better, when using alternatives to dissection;

- Guided learning, no matter whether with dissections or alternatives, brings both gains in declarative knowledge and personal satisfaction;

- Well-designed models, as substitutes for actual specimens, can produce equal performance in skills; and

- The use of interactive experiences that learners can control at their own pace is of benefit.

\section{What are the advantages of alternatives?}

Although the final arbitration on whether alternatives to dissection are worth using can be reduced to test scores, there are other considerations. These considerations will also effect a teacher's decision on using alternatives. 
Among them, one should include time issues, cost issues, the problems of confusion and frustration on the part of learners, and issues in the procurement and disposal of specimens.

Time Considerable time can be spent dissecting an animal. Furthermore, time can be spent in trying to gain some competence with the dissecting tools themselves (Clarke 1987). If procedural knowledge and skills are valued, then this time is well spent. However, if declarative knowledge is the goal, then some of that time is wasted. It would be far better to be on-task in declarative learning rather then kill time being busy with dissecting trays, pins, scalpels, and tweezers.

Costs An animal is expensive and can only be used once, and usually by no more than four learners. Balcombe (1997) noted that the Humane Society of the US found that a typical school could make significant savings each year by replacing animal dissection with alternatives. Initially, some of the alternatives may themselves appear very expensive. However, many learners can use videos, interactive videos, and soft-tissue organ models for years. Burkett (2000) made the pertinent comment that an institution on an already-tight budget should not ignore investment in computer hardware, software, and maintenance. He also pointed out that the costs of dissection equipment already purchased should not be ignored when drawing up a balance sheet.

Confusion and frustration We have noted that computer simulations and interactive video-discs enable learners to progress at their own pace. The limited research reported above shows that learners appear to benefit more in situations in which the simulation or video-disc carries a commentary, thereby providing guided discovery. Langley (1991) has made the constructivist point that learners can follow their own interests more effectively when they are given some flexibility in how they construct their own knowledge. Such learning is likely to reduce frustration and confusion on the part of the learners. They will be more satisfied with the learning experience.

Procurement and disposal All specimens have to be ordered from suppliers in advance. With live specimens, a tight schedule has to be applied to ensure that they do not become burdensome or deteriorate in condition. With computer simulations and videos, the equipment does need to be at hand, but it will be in the same institution, department, and room as the teacher.

Animal tissue has to be disposed of in a safe way, using the protocols agreed by provincial and national bodies. Procedures designed with health and safety in mind are already in place, and in many countries these procedures are open to scrutiny by an independent inspectorate. As regulations change, so the staff of the school department needs to be kept up-to-date. 


\section{What are the disadvantages of alternatives?}

Sensory experience We learn from the outside world through sensory experience. The more senses involved, the more powerful the learning experience. Learners viewing dissections with high-tech alternatives will not have the same sensory experience as learners examining actual animal tissues and organs. Viewing any alternative engages one or two of the senses, whereas actually doing the dissection engages at least three of the four senses.

Visual-spatial thinking Lord (1990) noted that activities such as handling, rotating, manipulating, and envisioning objects during dissection greatly contribute to the development of visual-spatial perception. Alternatives may not stimulate visual-spatial thinking in the learner so effectively.

Realism The feel of models and preserved specimens is definitely different from the feel of live and freshly-sacrificed specimens. Alternatives can be faulted for their lack of realism (Orlans 1988a, Kinzie et al. 1993, 1996). Greenfield et al. (1995) pointed out that some models used in his study were more friable than real tissues. Downie and Meadows (1995) emphasized that, to examine motile sperm in the reproductive system of the male, the model rat is distinctly second-best. Offner (1993) argued that when learners know a specimen is real, their attention is heightened, and the information they learn is somehow registered as 'real'. Leonard (1985) found that the learners in biology classes had a strong perception that the images on a video-disc learning system were not real.

Dissection skills If emphasis is placed on learning practical dissection skills, alternatives should not be considered as a replacement for an actual animal dissection. Quentin-Baxter and Dewhurst (1990) made the important point that the alternative programme, 'The Rat Stack', ${ }^{3}$ may help to prepare a learner for a dissection or provide a useful revision tool, but it cannot teach practical dissection techniques.

\section{In which terms are ethical considerations discussed?}

Ethical considerations on dissections are multiple. They are diverse, have different sources, and the justifications carry stronger, or weaker, arguments. Here, we note the most popular in the literature.

In Northern and Western countries, an increasing number of people have the pragmatic attitude that animal dissection is wrong, because it involves unnecessary killing. The ethical decision hinges on the argument of 'lack of necessity': if alternatives exist, animal sacrifice is unnecessary. 'Lack of necessity' may come from either having access to substitutes, as discussed above, or from abandoning the knowledge and skill demanded when dissection 
is a curriculum requirement. Clearly, 'lack of necessity' may have different justifications. Another line of reasoning is taken by those concerned about the pain and suffering the animal may experience on the way to the dissection table. However, both the lack-of-necessity and the pain-andsuffering viewpoint express ethical considerations that are animal-focused and external to the thinker. On the other hand, a weaker position, that is inwardly participant-focused, is simply that watching a dissection is unpleasantnot a very nice experience, and, therefore, wrong.

Those who think cutting a once-living body is a desecration can marshal much stronger arguments. Such opinions can have religious beliefs included in their rationalization. The justification of the ethics is transcendent rather than personal. God supplies the wrongness. However, somewhat surprisingly, a justification may also call upon biology itself for its arguments. Burkett (2000) asked the following important questions: Do humans, as a species, have a 'right' to dominion over animals? Do humans, as a species, have a superior place in the biosphere? If so, does that superior position grant a privilege to kill animals for learning activities? The post-Darwinian biologist is driven by an evolutionary perspective to respond to these questions with the answer of 'No'. Ethical opposition to dissection can make for strange bedfellows.

Some scholars recognize that an individual's position on ethical issues may be changed by their experiences. Orlans (1991) suggests that continued exposure to dissection can stiffen attitudes towards animal suffering and foster disrespect for animal life. Thus, ethical issues are overridden by technical and skills concerns. There is some truth in this argument. Why else do medical and nursing students need clinical training? Other evidence comes from daily routines of ordinary people. Think how cheerfully people buy chicken at the supermarket; yet how repelled most modern Northern and Western people would be by the suggestion that they should carry out their own slaughtering for the meat they eat. Removal from the sacrifice itself can cause human beings to objectify the resulting 'meat'. So perhaps, seemingly contradictorily, being present at the sacrifice, in preparation for a dissection, is just what is needed to add an appropriate ethical dimension.

Kline (1995) takes the liberal position in contending that if a learner believes deeply and sincerely that dissecting animals is morally wrong, educators should respect that learner's views and moral integrity. On the other hand, Kieffer (1979) takes a directive view in emphasizing that changes both in societal and in individual ethical perspectives are imperative. Settling ethical issues by allowing free choice is unacceptable. For Kieffer, this approach fosters an ethical pluralism in which any choice is as good as any other, and allows a moral free-for-all, which is incompatible with having a well-ordered society. Kieffer warns that unlimited freedom, be it social or ethical, carries with it the seeds of its own destruction. 
Kohlberg and Mayer (1972) took a pedagogical stand when they pointed out that the most important issue confronting educators and educational theorists is the choice of ends for the educational process. Without clear and rational learning outcomes, it becomes impossible to decide which educational programmes achieve learning outcomes of general import and which teach incidental facts and attitudes of dubious worth. Teachers supporting dissection in the biology classroom must present the option for use of alternatives if the learning outcomes can be met. However, Doster et al. (1997) contended that, if educators maintain that dissection is the only way to learn about animal anatomy, without regard to learners' ethical views, it is most unlikely that learners whose values raise objections to dissection will have a positive learning experience.

Agreement that there is value in including ethical discussions and encouraging critical thinking for learners can be attributed to representatives of the full spectrum of viewpoints on dissection (Rowan and Weer 1993). Most secondary and post-secondary teachers agree that raising ethical issues for classroom discussion is a healthy process (Nichols 1995). However, the majority of learners with an objection never tell their teachers about it. Balcombe (1997) suggests that the main reason for this silence is that many biology teachers unwittingly foster a classroom atmosphere that is closed to considering such ethical concerns.

\section{What are the learners' feelings about animal dissection?}

Given the limited research into the efficacy of alternatives to dissection, it is not surprising that few studies have investigated the attitudes of learners to animal dissection. Indeed, it was not until the late 1980s that such studies were undertaken. (Earlier it had been assumed that biology and dissection were indissoluble.)

Sieber (1986) examined undergraduate learners' and scientists' attitudes to animal research. More than half $(59 \%)$ of the respondents thought that there were better ways for students to learn some aspects of physiology and anatomy than by killing and dissecting animals. The majority (58\%) indicated that they wanted a choice of whether to perform dissections themselves or instead watch a real dissection or a film of a dissection when taking a course dealing with anatomy and physiology of animals.

Millett and Lock (1992) examined secondary school learners' attitudes towards the use of animals in schools. Only $32 \%$ indicated that they would find dissecting a dead animal interesting; 73\% thought that it was wrong to breed animals for dissections; and $38 \%$ said they would object to any animal material being used for dissection. Eighty-three per cent of females and $61 \%$ of males thought it was wrong to breed animals to be used for 
dissection.

The study of Stanisstreet et al. (1993) indicated that $48 \%$ of the secondary school learners thought that animal dissection was wrong. Bowd (1993), in a study of undergraduate learners' attitudes to animal dissection, found that $27 \%$ had exclusively negative reactions to dissection, while $38 \%$ reported both negative and positive reactions. Lord and Moses (1994) studied undergraduates' opinions of animal dissection. Nearly half (48\%) objected to the idea of dissecting a rabbit, $56 \%$ to dissecting a cat, and $67 \%$ to dissecting a monkey. A large proportion $(80 \%)$ of the learners did not object to the dissection of preserved animals.

In summary, it is clear that attitudes are changing at both the secondary and tertiary stages:

- there is a shift away from enjoying dissection as part of a biology programme; and

- few learners now think animals should be breed in captivity specifically for dissections.

\section{At which stage of education is dissection necessary?}

As educators, it is our responsibility to provide the best teaching and to encourage the greatest learning possible. To dissect, or not to dissect, is a question to be answered by reflecting on the learning outcomes of the curriculum. Learning outcomes can be sensory, cognitive and affective, ethical, skills-based, and procedural. At different stages in schooling, the curriculum shifts in terms of the content of learning outcomes and the balance among learning outcomes.

\section{Primary education}

Animal dissection is completely unnecessary in primary education. In fact, quite the reverse is required. Young primary learners need school experiences that help them to build an appreciation for the diversity of life. The nature-table helps them to see the variety of living organisms, plants, as well as animals.

For such learners, their immediate perception dominates their thinking. They will often treat slow-moving animals or slow-growing plants as inanimate. Work with young children suggests that they also use regeneration as a way of judging the living from the inanimate. Horror stories of small boys tearing the wings off insects are to be heard in virtually every primary staff-room at some time of the year. For small children, the term animal is restricted to mammals. They simply do not judge insects, or even 
fish, to be animals. They have to learn otherwise. This is not done by dissections.

\section{Secondary education}

At the secondary stage, dissection may be beneficial only to the few students hoping to study medicine or veterinary science, when that study begins immediately after the secondary school. It will help them to learn the basics of their professions: an experience of the methods of careful anatomical investigation, a sense of the texture of internal organs, and the satisfaction of discovery. A case used to be made that learners could be turned on, or off, biology by dissection. Dissection may, therefore, have had a filtering effect on those who found it so unpleasant that they would never have chosen a career in the biological field. However, is it wise to use a filter for the few at the educational expense of the many?

In many countries, that question is now redundant, given the changes in biology education at the secondary level in the last 40 years. Many of those changes have been accelerated by changes in biological research and thinking itself. Single organism studies now play a much smaller part in biology: there is more emphasis on ecology (habitats and communities) and cell action (physiological processes and biochemistry). Biology education has similarly moved in opposite directions, namely the larger and smaller units of analysis. Although 'structure and function' may still be included in the title of best-selling biology textbooks, that title no longer refers exclusively to the single organism.

In consequence, animal dissection no longer has such a prominent place in biology education at the secondary stage. Ecological studies examine organization and relationships outside the organism. Cell biology studies examine organization and structure that can only be seen with an electron microscope, re-agents, centrifuge, and electrophoresis bench.

Many biology teachers at the secondary level use colouring-in, cutandpaste activities (Yelverton 1991), and paper pop-up models (Miller and Pelham 1984) to teach structure and function. Students enjoy these activities and learn declarative knowledge. Note that no research studies have been done on these activities; they have been judged sound in widespread classroom use. In fact, colouring-in books are now often used in the training of physicians, in, for example, neuro-anatomy (Diamond et al. 1985).

\section{University-level education}

We agree with Orlans (1991) that there is a place for animal dissection in the training of mature learners who have made a career commitment where 
dissection can assist in the acquisition of necessary knowledge and skill. However, even at the tertiary stage, this concession does not mean that all learners in courses in biology should be carrying out dissections when alternatives may be perfectly adequate.

In the case of learners who will go on to become biology teachers at the secondary stage there is an interesting dilemma. On the one hand, it is much less likely that they will use dissections in the secondary school. On the other, it makes sense to have first-hand experience of what one is teaching. Perhaps, as in the case of physicians and veterinarians, dissections could be classified as vocationally necessary for biology teachers. At the same time, given the alternatives in the secondary stage, prospective biology teachers should have training in those alternatives.

\section{Dissection in biology education in South Africa}

In this section of the paper we return to our conjecture that what is taught in schools, colleges, and universities depends upon cultural conditions and pedagogic possibilities. We turn to South Africa, a country whose education system is in transition, to illustrate this argument. The situation in South Africa makes an interesting case-study because there are strong elements of Northern and Western culture cheek-by-jowl with elements of more traditional African culture.

\section{Biology in the national curriculum statement grades $R-9$}

In South Africa, national curricula in the natural sciences and life sciences have recently been introduced (Department of Education 2002a, b) and in the national curriculum statement for grades R-9 the word 'dissection' does not appear. In these documents, the National Department of Education has taken no standpoint on animal dissection in biology education and leaves the issue open. The document opens by noting that the people of South Africa operate with a variety of learning styles as well as with culturally-influenced perspectives. This is recognition of how past segregationist policies have perpetuated cultural diversity.

The curriculum statement for grades R-9 (Department of Education 2002a: 5) has been divided into four main content areas (termed 'knowledge strands'). One of the strands, 'Life and living', focuses on life processes and healthy living. The core-knowledge unifying statement for 'life processes and healthy living' requires that learners should study living things such as humans and invisibly small organisms that can be understood in terms of their life processes, functional units, and systems. There is no indication for the teacher as to how thoroughly each core-knowledge unit must be taught. Teachers are left to decide how, and to what depth, they will treat the topics. Two of these units in the intermediate phase and three in the senior phase 
deal with the anatomy and physiology of animals. Each of these core knowledge units may be approached through organ dissection as well as wholebody

dissection. There is no specific guidance in the documentation of the curriculum statements.

It is only in the best-resourced schools (the historically-advantaged schools: the old white schools) that one might find rats and frogs being dissected at grades 7-9. Such advantaged schools have teachers who are practised in dissection, together with the resources to continue teaching by way of dissection. For historically-disadvantaged schools (the old underresourced black schools), dissection was never a possibility. Thus, in South Africa what happens in any one school is determined by its cultural inheritance. Currently, know-how, class size, resources, and procurement are the determining factors: these are social factors, not factors inherent in biology education.

\section{Biology in grades 10-12}

The life sciences in the national curriculum statement for grades 10-12 (Department of Education 2002b) is organized around four knowledge areas. One of them is 'structure and control of processes in basic life systems', currently being taught with the aid of dissection. Secondary education, the gateway to tertiary education, has a vocational flavour and in South Africa those in these grades with aspirations to being physicians, dentists, opticians, veterinary surgeons, para-medics, etc., will follow pre-vocational biology-oriented programmes of study. What happens in any particular school depends upon parental and learner pressure for vocational success. Again, social factors, rather than those inherent in biology education, shape the classroom practice.

\section{Biology in the university}

Currently, dissection of organs and whole animals is used in many biology education programmes. Medical and veterinary studies are probably more advanced in their sparing use of dissection and wider use of alternatives because they are more cognizant of international training practices, and run programmes with larger budgets. Once more, these factors are social.

\section{Dissection in a social context}

The history of science records many ideas about the natural world which have been discarded by modern-day practitioners. Just as what is deemed good scientific practice and reliable scientific knowledge is in a state of evolution, so too is science education. In Northern and Western countries, science education in the last century has been characterized by a long march to making science available to all (Hodson 2003). The science that is suitable 
for all is not, and cannot be, the science that has been taught to an academic elite. One coping strategy that found great favour was to make science more hands-on with practical activities. In many countries, these have recently been transformed into investigations. However, even though an increased emphasis on investigatory work has impacted what goes on in school classrooms and laboratories, such investigations are still very much an education in science rather than an education about science (Wellington 1998).

As society changes, so too what is expected from a science education also changes. Such reports as 'Beyond 2000: science education for the future' (Millar and Osborne 1998) have proposed a shift in balance away from education in science towards education about science. An education about science might provide learners with a science for citizenship, rather than a science to win a Nobel prize. This approach acknowledges the need to provide future citizens with 'scientific literacy' (Aikenhead 1990). Such literacy would enable citizens to understand how a scientific argument was being constructed and how evidence was being collected and marshalled in support of the case being made. (Whether it is possible to achieve this goal remains to be tested.)

Dissection, as a topic, may appear in a science for citizenship. However, its aim would not be to develop learners' manipulative skills, visual-spatial awareness, and mental modelling of the internal structure of an organismor memory of the organisms' organs, their distribution, and scientific names. Instead, if dissections did appear as a topic in science for citizenship, learners would be more likely to discuss the type of knowledge a dissection can bring, the need for dissections in different social situations (e.g. pathological studies), the ethical issues of dissection and vivisection, and the costs, benefits, rights, and responsibilities involved. The epistemological question 'How do we know?' would feature more than the ontological question 'What is there?' Allchin (1991) pointed out that scientists cannot construct a picket-fence around their practice and claim that, within that domain, they also define what is morally right or wrong. It is the society within which science is located that attempts such definitions. Dissection, as a scientific activitywhat is done and how it is managed-provides one indicator of the state of any given society at any given time. The question of what is or is not acceptable, good practice, or morally repugnant within dissection work is an empirical question. The study of that question can only confirm how the way dissections are addressed is contingent on social location.

\section{Acknowledgements}

We acknowledge the Commonwealth Scholarship Commission for providing the opportunity that made this review possible. We also wish to thank the referees of earlier submissions for their useful comments. 


\section{Notes}

1. Historians of medicine disagree on how Galen's evidence was collected. Some of his ideas

on anatomy contradict the notion that he worked on living animals.

2. Guerrini (2003) provides a useful and illuminating summary.

3. For details of 'The Rat Stack' and related resources, see Learning and Teaching (2004).

\section{References}

Aikenhead, G. S. (1990) Scientific/technological literacy, critical reasoning, and classroom practice. In S. P. Norris and L. M. Phillips (eds), Foundations of Literacy Policy in Canada (Calgary, AB: Detselig), 127-145.

Allchin, D. (1991) Dissecting classroom ethics. The Science Teacher, 58(1), 4449.

Balcombe, J. (1997) Student/teacher conflict regarding animal dissection. The American Biology Teacher, 59(1), 22-25.

Bowd, A. D. (1993) Dissection as an instructional technique in secondary science: choice and alternatives. Society and Animals, 1(1), 83-88.

Burkett, R. S. (2000) To dissect or not to dissect. Available online at: http://www.rburkett.org/Dissect.htm, visited 27 December 2004.

Clarke, K. A. (1987) The use of microcomputer simulations in undergraduate neurophysiology experiments. Alternatives to Laboratory Animals, 14(3), 134140.

Davis, P. (1997) Dissection symposium: a meeting of minds? National Antivivisection Society Bulletin, Winter edition, 22-29.

Department of Education (2002a) Revised National Curriculum Statement Grades R-9 (Schools) Policy, Natural Sciences (Pretoria, South Africa:

Department of Education). Available online at:

http://education.pwv.gov.za/content/documents/12.pdf, visited 14 July 2004.

Department of Education (2002b) National Curriculum Statement Grades 10-12 (Schools) Life Sciences (Pretoria, South Africa: Department of Education). Available online at: http://education.pwv.gov.za/content/documents/110.pdf, visited 14 July 2004. 
Dewhurst, D. G., Hardcastle, J., Hardcastle, P. T. and Stuart, E. (1994) Comparison of a computer simulation program and a traditional laboratory practical class for teaching the principles of intestinal absorption. Advances in Physiology Education, 267(6), 95-104.

Diamond, M. C., Scheibel, A. B. and Elson, L. M. (1985) The Human Brain Coloring Book (New York: HarperPerennial).

Doster, E. C., Jackson, D. F., Oliver, J. S., Crockett, D. K. and Emory, A. L. (1997) Values, dissection, and school science: an inquiry into students' construction of meaning. Available online at: http://www.ed.psu.edu/ci/Journals/97pap7.htm, visited 15 January 2003.

Downie, R. and Meadows, J. (1995) Experience with a dissection opt-out scheme in university level biology. Journal of Biological Education, 29(3), 187-194.

Fowler, H. S. and Brosius, E. J. (1968) A research study on the values gained from dissection of animals in secondary school biology. Science Education, 52(1), 55-57.

Gilmore, D. R. (1991) Politics and prejudice: dissection in biology education, Part 2. The American Biology Teacher, 53(5), 272-274.

Greenfield, C. L., Johnson, A. L., Shaeffer, D. J. and Hungerford, L. L. (1995) Comparison of surgical skills of students trained using models or live animals. Journal of the American Veterinary Medical Association, 206(12), 1840-1845.

Guerrini, A. (2003) Experimenting with Humans and Animals: From Galen to Animal Rights (Baltimore, MD: Johns Hopkins University Press).

Hodson, D. (2003) Time for action: science education for an alternative future. International Journal of Science Education, 25(6), 645-670.

Jones, N. A., Olafson, R. P. and Sutin, J. (1978) Evaluation of a gross anatomy program without dissection. Journal of Medical Education, 53(3), 198-205.

Keiser, T. D. and Hamm, R. W. (1991) Dissection: the case for. The Science Teacher, 58(1), 13, 15.

Kieffer, G. H. (1979) Can bioethics be taught? The American Biology Teacher, 41(3), 176-180.

Kinzie, M. B., Larsen, V. A., Burch, J. B. and Boker, S. M. (1996) Frog dissection via the world-wide web: implications for widespread delivery of instruction. Educational Technology Research and Development, 44(2), 59-69. 
Kinzie, M. B., Strauss, R. and Foss, J. (1993) The effects of an interactive dissection simulation on the performance and achievement of high school biology students. Journal of Research in Science Teaching, 30(8), 989-1000.

Kline, A. D. (1995) We should allow dissection of animals. Journal of Agricultural and Environmental Ethics, 8(2), 190-197.

Kohlberg, L. and Mayer, R. (1972) Development as the aim of education. Harvard Educational Review, 42(4), 449-496.

Langley, G. R. (1991) Animals in science education—ethics and alternatives. Journal of Biological Education, 25(4), 274-279.

Learning and Teaching (2004) Resources: Learning and Teaching Support Network subject centre for Medicine, Dentistry and Veterinary Medicine, School of Medical Education, Faculty of Medical Sciences, University of Newcastle, Newcastle upon Tyne, UK. Available online at: http://www.Itsn01.ac.uk/resources/features/rats, visited 26 June 2004.

Leonard, W. H. (1985) Biology instruction by interactive video-disc or conventional laboratory: a qualitative comparison. Paper presented at the annual meeting of the National Association for Research in Science Teaching. ERIC ED 258811.

Leonard, W. H. (1989) A comparison of student reactions to biology instruction by interactive video-disc or conventional laboratory. Journal of Research in Science Teaching, 26(2), 95-104.

Lock, R. (1993) Bovine eyeball dissection in schools and colleges. Journal of Biological Education, 27(3), 157.

Lord, T. R. (1990) The importance of animal dissection. Journal of College Science Teaching, 19(6), 330-331.

Lord, T. R. and Moses, R. (1994) College students' opinions about animal dissections. Journal of College Science Teaching, 23(5), 267-270.

Mccollum, T. L. (1988) The effect of animal dissections on student acquisition of knowledge of and attitudes toward the animals dissected. ERIC ED 294749.

Millar, R. and Osborne, J. F. (eds) (1998) Beyond 2000: science education for the future (London: School of Education, King's College, University of London). Available online at:

http://www.kcl.ac.uk/depsta/education/publications/bey2000.pdf, visited 13 July 2004. 
Miller, J. and Pelham, D. (1984) The Facts of Life: A Three-Dimensional Study (London: Jonathan Cape).

Millett, K. and Lock, R. (1992) GCSE students' attitudes towards animal use: some implications for biology/science teachers. Journal of Biological Education, 26(3), 204-208.

Nichols, J. R. (1995) Values \& biology education. The American Biology Teacher, 57(5), 268-271.

Offner, S. (1993) The importance of dissection in biology teaching. The American Biology Teacher, 55(3), 147-149.

Orlans, F. B. (1988a) Debating dissection. The Science Teacher, 55(8), 36-40.

Orlans, F. B. (1988b) Should students harm or destroy animal life? The American Biology Teacher, 50(1), 6-12.

Orlans, F. B. (1991) Dissection: the case against. The Science Teacher, 58(1), 12, 14.

Prentice, E. D., Metcalf, W. K., Quinn, T. H., Sharp, J. G., Jensen, R. H. and Holyoke, E. A. (1977) Stereoscopic anatomy: evaluation of a new teaching system in human gross anatomy. Journal of Medical Education, 52(9), 758-763.

Quentin-Baxter, M. and Dewhurst, D. (1990) A computer-based atlas of a rat dissection. Humane Innovations and Alternatives in Animal Experimentation: A Notebook, 4, 147-150.

Rowan, A. N. (1981) Perspectives: animals in education. The American Biology Teacher, 43(5), 280-282.

Rowan, A. N. and Weer, J. C. (eds) (1993) Biology Education and Animals: Opportunities and Issues: Summary Proceedings (North Grafton, MA: Tufts Center for Animals and Public Policy, School of Veterinary Medicine, Tufts University).

Sieber, J. E. (1986) Students' and scientists' attitudes on animal research. The American Biology Teacher, 48(2), 85-91.

Smith, W. (1990) Dissection and use of animals in schools. The Australian Science Teachers Journal, 36(4), 46-49.

Stanisstreet, M., Spofforth, N. and Williams, T. (1993) Attitudes of children to the uses of animals. International Journal of Science Education, 15(4), 411-425. 
Strauss, R. T. and Kinzie, M. B. (1991) High-tech alternatives to dissection. The American Biology Teacher, 53(3), 154-158.

Wellington, J. (ed.) (1998) Practical Work in School Science: Which Way Now? (London: Routledge).

Welser, J. R. (1969) An evaluative investigation of silent loop films in the teaching of anatomy: Final report (Lafayette, IN: Purdue University). ERIC ED 029796.

Wheeler, A. G. (1993) Justifying the dissection of animals in biology teaching. The Australian Science Teachers Journal, 39(3), 30-35.

Yelverton, B. (1991) Reverse dissection. The Science Teacher, 58(6), 72-74. 